\title{
The Effect of Autocratic, Participative, and Delegation Leadership on Work Motivation of Indonesian Navy Personnel
}

\author{
Heribertus Yudho Warsono ${ }^{1}$, Budiyanto ${ }^{2}$, Akhmad Riduwan ${ }^{3}$ \\ ${ }^{1,2,3}$ Sekolah Tinggi Ilmu Ekonomi Indonesia, STIESIA \\ Surabaya, Indonesia
}

\begin{abstract}
The purpose of the study was to determine the effect of autocratic leadership style (X1), participatory (X2) and delegation (X3) on work motivation (Y) Navy Personnel. The research method used was a questionnaire with a sample of 55 people. Measurement of variables using Linkert scale techniques with 1-5 weighting values. To find out the relationship between variables $\mathrm{X} 1, \mathrm{X} 2$ and $\mathrm{X} 3$ to $\mathrm{Y}$ using statistical techniques correlation analysis, simple linear regression, and multiple linear regression, and to test the significance level using the test which is processed using the Statistical Product and Service Solution (SPSS) version 15 program. The conclusion of this study is that there is a strong influence from the autocratic leadership style, participatory and delegation on the work motivation of the Indonesian Navy Personnel. Then it was recommended to the Leaders at the Indonesian Navy Officers, to be able to maintain and continue to develop autocratic leadership styles, participatory leadership styles, and Delegation leadership styles to better achieve organizational goals. Increased work motivation can be done by increasing the ability of officers through training or leadership for Navy Personnel who have good work performance, giving incentives or rewards to outstanding soldiers and civil servants.
\end{abstract}

Keyword: Autocratic Leadership Style, Participatory Leadership Style, Delegation Leadership Style, Work Motivation

\section{Introduction}

A reality in the life of the organization, that the leadership and leadership play a very important role, even can be said to be very decisive in the effort to achieve the goals previously set. Leadership is a process or series of activities that are interconnected with one another, namely moving, guiding and directing and supervising others in doing things, both individually and together. All activities can be referred to as an effort to influence feelings, thoughts, and behavior of others in the direction of achieving a goal, therefore leadership is also a process of interaction between leaders and employees / down to do something that is in accordance with the goals of the company [1].

Leaders may not be able to work alone, but need a group of others who in popular terms are called subordinates, who are driven in such a way that subordinates provide service and contribution to the organization, especially in ways that work efficiently, effectively and productively. There are several leadership styles that are developing at this time [2], including:

1. Autocratic leadership is also called dictatorial or directive leadership.

2. Participatory leadership means involving team members in making decisions.

3. Delegation style leadership involves assigning new responsibilities to subordinates and additional authority to implement them.

The kinds of leadership styles that are applied in an organization can help create positive work motivation for employees. The existence of a leadership style that is in accordance with the situation and condition of the organization, the employee will be more motivated in carrying out their duties and obligations and have hopes of fulfilling their needs [5]. 
The phenomena that occur, namely the decreasing work motivation of the Navy Personnel, this can be seen by the presence of the Navy Personnel who are less active in carrying out their duties according to their duties and responsibilities, do not care about their duties and responsibilities, and there is no concern from soldiers and civil servants to take advantage of free time, to do things that are positive and beneficial for themselves and for the progress of the organization [3].

Based on the background of the problem above, the formulation of the problem is composed of how the autocratic, participatory and delegating leadership style and work motivation of the Navy Personnel, and whether the autocratic, participatory and delegate leadership styles have a significant effect on the work motivation of Navy Personnel. Based on the formulation of the above problem, this research was conducted with the aim of: to find out the autocratic, participatory and delegating leadership style and work motivation of the Navy Personnel and to find out the influence of autocratic, participatory leadership style and delegation on the work motivation of Indonesian Navy Personnel [13].

\section{Material And Methods}

\section{Leadership}

Leadership is a process of reciprocal relationships between leaders and followers in mobilizing various economic, political and other resources to achieve the stated goals. Leadership is a group of activities observed by other parties, taking place in groups, organizations or institutions, and involving leaders and followers who work together to realize the planned general goals. Leadership is also interpreted as the ability to get people to ignore what they do not like and do what they like. [4].

Leadership is the process of influencing others, to understand and agree with what needs to be done and how the task is carried out effectively, and the process to facilitate individual and collective efforts to achieve common goals. Leadership is the ability to influence a group towards achieving a goal. The broad definition of leadership includes the process of influencing in determining organizational goals, motivating follower behavior to achieve goals, influencing to improve the group and culture. Leadership behavior has a tendency to two things, namely consideration or relationship with subordinates and the structure of initiation or results achieved. Leadership tendencies describe relationships that are familiar with subordinates such as being friendly, helping and defending the interests of subordinates, willing to accept subordinate consultations and provide welfare [6].

Based on some understanding of leadership from several theories and opinions, it can be concluded that leadership is the ability of someone to direct, influence, encourage and influence others or subordinates to be able to do work on awareness and voluntary in achieving a certain goal. In an effort to implement effective leadership, in addition to having the ability and skills in leadership, a leader should determine the right leadership style in accordance with the situation and condition of group members.

\section{Leadership Style}

Leadership style contains an understanding as an embodiment of the behavior of a leader, which concerns his ability to lead. The embodiment usually forms a certain pattern or shape. This understanding of leadership style is in accordance with the opinion which states that the overall pattern of action of the leader as perceived or referred by the subordinates is known as the leadership style [7].

Leadership style is a normal behavior used by someone when the person tries to influence the behavior of others as he sees it. The leadership style in the organization is needed to develop a conducive work environment and build a climate of motivation for employees so that it is expected to produce high productivity.

Leaders cannot use the same leadership style in leading each of their subordinates but must be adapted to the characteristics and level of ability in the tasks of each subordinate. An effective leader in applying a certain style in his leadership must first understand whom his subordinates are leading, understand the strengths and weaknesses of his subordinates, and understand how to use the power of subordinates to compensate for their weaknesses [8].

\section{Military Leadership}

Leadership models in the military environment which generally emphasize stimulation on aspects of procedures, obedience to principles, etc., And communication styles are instructional and one-way. For the purpose of conditioning or forming behavior, the model of coaching and communication style is quite 
effective and still needed. But if the goal is directed at developing creative thinking patterns, it is necessary to adjust coaching methods that can stimulate flexibility in thinking.

The military is an entity that is strongly indoctrinated, which is implemented in the mindset, speech patterns, and patterns of actions of its members in daily life. Indoctrination which has been established since a (civil) citizen decides to become a military will ultimately bear fruit in the form and personal posture when he graduated from his education and effectively become a member of the military [8].

In the era of information technology development and very dynamic as it is today, there are three main issues faced by military leaders as follows:

1. Challenges to military leadership;

2. Changes in social structure;

3. Changes in economic dynamics.

From the three main issues, it is very unlikely that military leaders and their leadership will have an impact on changes in social structure and economic development. A fact is that in the past, registering to become a military was purely to defend the country, not to get paid or money. This paradigm shifted where the current generation views the military as a career entity [12].

The continuing impact of this paradigm shift is the addition of a greater burden of responsibility for leaders to maintain the motivation of the very "career-oriented" people they lead. The key to success for the current military leader in being able to lead in the same quality as the past military leaders lie in the development and formation of the military leader itself. Therefore, (prospective) military leaders must be adequately equipped with a certain capacity that allows them to adapt to the accelerating changes [10].

Future leaders are intelligence soldiers, who are capable of acting as managers, bureaucrats, specialists, as well as citizens with high situational awareness. They are obedient officers, who think before acting, who are young but mature, and who are idealistic but also realistic [14].

From the description above, it seems obvious that true leadership is a function of the ability and style of the leader, faced with their needs and values led, and the demands of the situation. That is why military leaders must understand both those they lead, and the situation surrounding them. That way he will find the right approach in carrying out his leadership to achieve the goals of his unit [11].

\section{Operational Definition of Research Variables Autocratic Leadership Style $\left(\mathrm{X}_{1}\right)$}

The autocratic leadership style is leadership based on power that must be obeyed. This leader always wants to act as a single player, his egoism is very large and tends to overrun organizational values that revolve around justifying all the means taken to achieve his goals [16]. The measurement indicator is based on

1. The organization he leads is private property.

2. Identify personal goals with organizational goals.

3. Assume subordinates as tools

4. Do not want to accept opinions, suggestions, and criticism from its members.

5. Too dependent on formal power

6. The way to move subordinates with a coercive approach and to be fault-finding.

\section{Participatory Leadership Style $\left(\mathbf{X}_{2}\right.$.).}

The leadership style of participation is the manager's response that must be played when the employee has a sufficient level of ability but does not have the willingness to take responsibility. This can be due to the low work ethic or their lack of confidence in carrying out tasks/responsibilities [16]. The indicators of the participatory leadership style used in this study are:

1. Consult with people before making changes

2. Explain that a proposal is temporary

3. Record ideas and suggestions

4. Look for ways to build ideas and suggestions

5. Speak tactically in concerns to be suggestions

6. Listen to the views of people who refuse without becoming defensive

7. Try to use suggestions and face concerns

8. Show appreciation for suggestions. 


\section{Delegation Leadership Style $\left(\mathbf{X}_{3}\right)$}

This delegation leadership style is also known as democratic leadership, consultative or consensus. Leaders who use this style involve subordinates in making decisions, which in turn must implement the decision. Subordinates are asked to give ideas or input about a problem, but those who make decisions are the leaders [15]. The indicators of the delegation leadership style used in this study are:

1. Explanation and agreement on suggestions/targets

2. Give support if needed

3. Representing the group to other parties

4. Avoid interference

5. Give responses to requests/demands seriously

\section{Work motivation (Y)}

Given the work motivation, in this case, the Indonesian Navy Personnel, work motivation is interpreted as an encouragement so that members of the unit can work in accordance with what is expected of the unit. Giving motivation to employees can influence activities for companies in improving the quality of work [6]. The indicators of work motivation:

1. Always present in the unit on time

2. Starting the implementation of the unitary task in a timely manner

3. Carry out the responsibility of full responsibility

4. Having high work initiative and creativity

5. Commitment and loyalty to the task of unity

6. Dexterous attitude and responsiveness to carrying out work tasks

7. Carry out the task whole

\section{Research Framework}

Based on the title, problem formulation and research objectives, the concept of this research is to look for the influence of the autocratic, participatory leadership style and delegation on the work motivation of the Navy Personnel, the model of this research framework are:

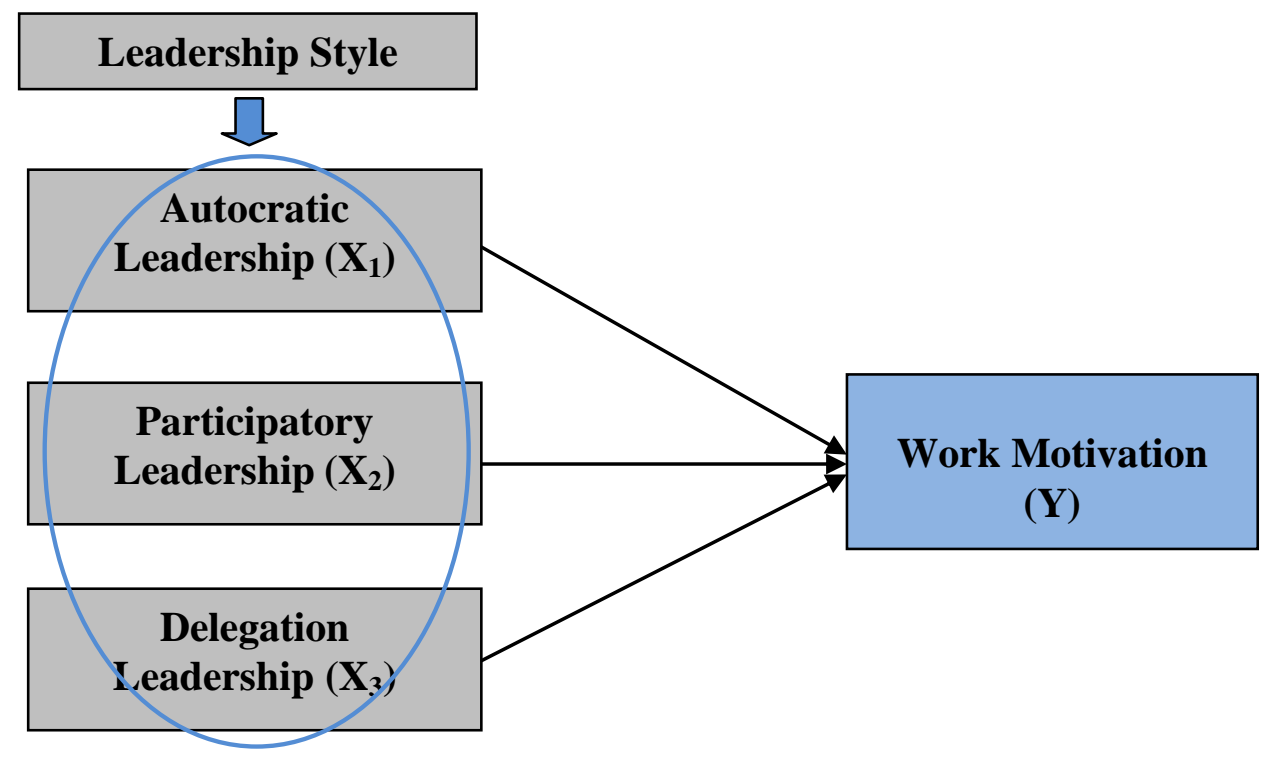

Figure 1. Research Framework Model

\section{Research Hypothesis}

From the formulation of the problem, the purpose of the research, the theoretical basis and has been outlined in the framework of the mind, then the hypothesis can be made as follows:

1. It is suspected that there is an influence between the autocratic leadership styles on the work motivation of the Navy Personnel.

2. It is suspected that there is an influence between participatory leadership styles on the work motivation of the Navy Personnel. 
3. It is suspected that there is an influence between the delegation's leadership styles on the work motivation of the Navy Personnel.

This study aims to explain the effect of independent variables on the dependent variable, this study is classified into the type of explanatory research, where this study explains the influence of autocratic leadership, participatory and delegation on the work motivation of the Navy Personnel.

\section{Data Collection and Analysis Techniques}

To be able to analyze and interpret valid and reliable data, so that the results obtained contain the truth. In this study the data collection techniques used are:

1. Documentation Study. The researcher seeks to examine and collect documents or archives that are representative of the problems that are submitted as authentic evidence sourced from books, journals and data at the Center for Advanced Education Officers Indonesian Navy, which are in accordance with the concepts in this study.

2. Questionnaire Technique. Questionnaire technique is by disseminating or conveying questions in writing. In the questionnaire the researcher only used closed types of questions (Closed question), that is the respondent's question just choose one of the alternative answers desired by the respondent.

3. Data processing, the researcher used a tool in the form of a computer application program, namely the Statistical Product and Service Solution (SPSS) program Version 15.

The tool used to collect data is a questionnaire in the form of a questionnaire, answers are arranged in a Likert Scale five choices of answers with the weight of the score as follows:

Score 5: Strongly agree

Score 4: Agree

Score 3: Moderate Agree

Score 2: Less Agree

Score 1: Disagree

\section{Test the Validity and Reliability of Research Instruments}

1. Validity Test.

An instrument is said to have high validity if the instrument can carry out its measuring function, or provide accurate and accurate measurement results in accordance with the intended use of the instrument. Measurement of validity on this instrument is done by product moment correlation between item scores and scale scores [9]. The correlation coefficient can be considered satisfactory if it exceeds 0.30 .

2. Reliability Test.

Reliability test is intended to find out the consistency of measuring instruments in their use or in other words the measuring instrument has consistent results when used multiple times at different times [9]. For this reliability test, Alpha Cronbach's technique is used $>0.60$.

\section{Result and Discussion}

\section{Characteristics of Respondents}

The characteristics of the respondents are the distribution of the respondents involved in the study. The research was conducted at the Indonesian Navy Officers' Center for Advanced Education which had the strength of 55 Navy Personnel (include Soldiers and Civil Servants), all of whom could fill out and return the Questionnaires given. The characteristics of the respondents in this study are as follows:

1. The majority are 52 or $91.02 \%$ Male soldiers

2. The majority of staff are 34 soldiers or $61.82 \%$

3. Total of 52 active soldiers or $91.02 \%$

4. Most high school educators have 39 soldiers or $70.91 \%$

5. Based on rank, Middle Officer has 12 soldiers or $21.82 \%$ and those with the rank of First Officer have 8 soldiers or $14.55 \%$ while those with the rank of Master Chief have 30 soldiers or $53.55 \%$ and those with the rank of Enlisted are as many as 2 soldiers or equal to $3.64 \%$ then those included in Civil Servants are 3 people or $5.45 \%$. 
Table 1. The Value of Instrument Reliability Test

\begin{tabular}{|c|l|c|l|}
\hline No. & \multicolumn{1}{|c|}{ Research Variable } & $\begin{array}{c}\text { Value of } \\
\text { Alpha } \\
\text { Cronbach }\end{array}$ & Result \\
\hline 1 & Autocratic Leadership Style $\left(\mathrm{X}_{1}\right)$ & 0,8522 & Reliable \\
2 & Participatory Leadership Style $\left(\mathrm{X}_{2}.\right)$. & 0,8622 & Reliable \\
3 & Delegation Leadership Style $\left(\mathrm{X}_{3}\right)$ & 0,8350 & Reliable \\
4 & Work motivation (Y) & 0,8977 & Reliable \\
\hline
\end{tabular}

\section{Hypothesis Testing Results.}

Hypothesis test results show that the autocratic, participatory and delegated leadership styles are tested and have a significant effect on the work motivation of Navy Personnel. This is supported by the results of the analysis which shows that the work motivation of Navy Personnel is determined by autocratic, participatory and delegated leadership styles. There is a significant effect between the leadership style of the employer and employee motivation [15]. A leader in carrying out his work always works with the help of others, in this case, his subordinates. In carrying out its work a subordinate can do it well or not, depending on the leader, if the job is done well, then that is what a leader wants, but if the work cannot be done well, this is the role of a leader who is expected to give encouragement and motivation towards these subordinates so that the expected performance will be achieved.

\section{Effect of Autocratic Leadership Style on Work Motivation.}

The regression coefficient results for the autocratic leadership style variable towards work motivation (Y) of 0.388 . The magnitude of the regression coefficient with a positive sign indicates that the influence of the autocratic leadership style on work motivation (Y) at the Officer Education Center has a positive influence, which means that whenever there is an increase in one unit of incentives, it will be followed by increased work motivation (Y) amounting to 0.388 in the constant 17.568. Increased work motivation can be seen clearly, that autocratic leadership style contributes positively to improving performance. The autocratic leadership style was tested to have a positive and significant effect on the work motivation of the Navy Personnel, thus the more applied the autocratic leadership style would have a real impact on the performance improvement of the Navy Personnel.

\section{Effect of Participatory Leadership Style on Work Motivation.}

The regression coefficient for the participatory leadership style variable on work motivation (Y) at the Center for Education Continued Officer was 0.676. The magnitude of the regression coefficient with a positive sign shows that the influence of the participatory leadership style variable on work motivation (Y) at the Officer Education Center has a positive influence, which means that every increase in one unit score participatory leadership style will be followed by increased work motivation (Y) at the Center for Advanced Education Officers, amounting to 0.676 at the constant 17.568. Increased work motivation can be seen clearly, that participatory leadership style contributes positively to improving performance. Work motivation of Navy Personnel in the Officers' Center for Advanced Education, is also influenced by participatory leadership styles, thus the application of participatory leadership by leaders can be used to improve the performance of its members. In participatory leadership, leaders carry out their leadership consultatively by accommodating various opinions and thoughts from subordinates regarding the decisions to be taken.

\section{Effect of Delegation Leadership Style on Work Motivation.}

The regression coefficient results for the Delegation leadership style variable on work motivation (Y) at the Indonesian Navy Officers; Center for Advanced Education, amounting to 0.537. The magnitude of the regression coefficient with a positive sign shows that the influence of the Delegation leadership style variable on work motivation $(\mathrm{Y})$ at the Officer Education Center, there is a positive influence, which means that every increase in one unit score of Delegation leadership style will be followed by increased work motivation (Y) at the Center for Advanced Education Officers, amounting to 0.537 at the constant 17.568. Increased work motivation can be seen clearly, that the Delegation leadership style contributes positively to improving performance. 
Delegation leadership style is also a variable that has a positive and significant effect on the work motivation of Soldiers and Civil Servants in the Officers' Center for Continuing Education, this delegation of authority by leaders to subordinates in carrying out their duties will cause higher performance of subordinates. In the delegation leadership style, the leader fully surrenders the work assignment to the member, so that the member is fully responsible for the successful completion of the work

Thus it is very clear that in accordance with this concept, the work motivation of Navy Personnel serving in the Indonesian Navy Officers; Center for Advanced Education can be significantly affected by the quality of autocratic leadership styles, participatory leadership styles, and Delegation leadership styles.

\section{Conclusion}

Based on the results of the analysis and discussion, the results of this study can be summarized as follows:

1. Based on the results of the frequency distribution of scores, respondents have relatively high responses to the statements in the questionnaire which are used as indicators of measurement of autocratic leadership styles, participatory leadership styles, and Delegation leadership styles, and work motivation of soldiers. Thus, the autocratic leadership style, participatory leadership style, and Delegation leadership style, as well as the work motivation of Navy Personnel in the Center for Advanced Education of Indonesian Navy are included in the good category.

2. Autocratic, Participatory and Delegate leadership styles significantly influence the work motivation of Navy Personnel for Advanced Education Officers. Thus a combination of Autocratic, Participatory Leadership and Delegation by leaders can increase the work motivation of Indonesian Navy Personnel.

\section{Acknowledgement}

The authors greatly acknowledge the support from Sekolah Tinggi Ilmu Ekonomi Indonesia STIESIA Surabaya and Indonesian Navy Institution for providing necessary resources to carry out this research work. The authors are also grateful to the anonymous reviewers and journal editorial board for their many insightful comments, which have significantly improved this article.

\section{References}

[1] Allan Wigfeld, Susan L. Klauda, and Jenna Cambria, Influences on the Development of Academic Self-Regulatory Processes, Department of Human Development, University of Maryland, 2017.

[2] David Okurame, Impact of Career Growth Prospects and Formal Mentoring on Organizational Citizenship Behaviour, Leadership \& Organization Development Journal, Vol. 33 Issue: 1, hh.6685, 2012.

[3] Dessler, Gary, Human Resource Management, Fourteenth Edition, Essex, England: Pearson, 2015.

[4] Eeman Malik, Organizational Citizenship Behaviour, Job Performance, and HR Practices: A Relational Perspective. Management and Labour Studies, Vol. 39, pp. 449-460, 2015.

[5] Fred Luthans, Organizational Behavior, An Evidence-Based Approach, 12th Edition, New York: McGraw-Hill, 2011.

[6] Harvey N. Switzky, Personality and Motivational Differences in Persons with Mental Retardation, New Jersey: Lawrence Erlbaum Associates Publishers, 2001.

[7] John R. Schermerhorn, Hames G. Hunt, Richard N. Osborn, and Mary Uhl-Bien, Organization Behavior, 11th Edition, USA: Jhon Wiley \& Son, 2011.

[8] Johnson, W. Brad dan Andersen, Gene. R., Mentoring in the US Navy, Naval War College Review, Vol. 68, 2015.

[9] Joseph F. Hair, Jr, William C. Black, Barry J. Babin, and Rolp E, Anderson, Multivariate Data Analysis: A Global Perspective, New Jersey: Pearson Education, Inc, 2010.

[10] Khalid Farooq, Organization Citizenship Behaviour a Key for Employee Retention: An Empirical Investigation from Systematic Institutional Industry Pakistan, Journal of Political Sciences \& Public Affairs, 2015.

[11] Marguerite G. Lodico, Dean T. Spaulding, and Katherine H. Voegtle, Methods in Educational Research, From Theory to Practice, Second Edition, USA: John Wiley \& Sons, 2010. 
[12] Mumtaz Ali Memon, The Relationship Between Training Satisfaction, Organisational Citizenship Behaviour, and Turnover Intention: A PLS-SEM Approach, Journal of Organizational Effectiveness; People and Performance, Vol. 4 Issue: 3, pp.267-290, 2017.

[13] Ricky W. Griffin and Gregory Moorhead, Organizational Behavior, Managing People and Organizations, $11^{\text {th }}$ Edition, Australia: South-Western, 2014.

[14] Robert L Mathis, John H.Jackson, Human Resource Management, Thirteenth Edition, Ohio: SouthWestern Cengage Learning, 2011.

[15] Robert Kreitner and Angelo Kinicki, Organizational Behavior, Ninth Edition, New York: McGrawHill, 2010.

[16] Scott Snall, \& George Bohlander, Principles of Human Resource Management, $15^{\text {th }}$ Edition, Ohio: South-Western Cengage Learning, 2010. 